\title{
PERISTIWA-PERISTIWA YANG MEMBUAT BAHAGIA
}

\author{
Harmaini, Alma Yulianti \\ UIN Sultan Syarif Kasim Riau, Pekanbaru, Riau \\ e-mail: uda_harmen72@yahoo.com
}

\begin{abstract}
This research aimed to explore the events that experienced and made the teens happy. The survey method was conducted with a total sample of 51 boys and 159 girls of high school students in Pekanbaru City. The instrument was an open-ended question and the data processed by descriptive analysis. Based on the research results, the three major components that events make teens happy namely (1) Relation by $55.7 \%$ includes events related to parents, family and peers. (2) Personal affective by $34.7 \%$ of the events associated with the opposite sex, affection, the psychological benefits, hobbies, etc., and (3) achievement by $24.7 \%$ includes events associated with achievement, graduation, ability to complete the task, and satisfactory result.
\end{abstract}

Keywords: event, happiness, teens

\begin{abstract}
Abstrak
Penelitian ini bertujuan mengeksplorasi peristiwa yang dialami dan membuat remaja bahagia dengan metode survei kepada sampel remaja SMA sebanyak 51 laki-laki dan 159 perempuan di Kota Pekanbaru. Alat ukur yang digunakan adalah open-ended question dan pengolahan data menggunakan analisis deskriptif. Berdasarkan hasil penelitian, tiga komponen besar peristiwa yang membuat remaja bahagia, yaitu (1) Relasi sebesar 55,7 \% meliputi peristiwa-peristiwa yang berhubungan dengan orangtua, keluarga dan teman sebaya. (2) Personal afektif sebesar 34,7\% yakni peristiwa-peristiwa yang berhubungan dengan lawan jenis kelamin, mendapatkan kasih sayang, imbalan psikologis, hobi, dan lain-lain, serta (3) Prestasi sebesar 24,7\% meliputi peristiwa-peristiwa yang berhubungan dengan prestasi, kelulusan, mampu menyelesaikan tugas, dan hasil yang memuaskan.
\end{abstract}

Kata Kunci : peristiwa, kebahagiaan, remaja

\section{PENDAHULUAN}

\section{A. Latar Belakang Masalah}

Kebahagaian adalah suatu perasaaan yang dapat dialami oleh semua orang, namun cara orang untuk memperoleh kebahagian itu berbeda-beda tergantung bagaimana seseorang mempersepsikan kebahagiaan tersebut. Ada yang mengatakan apabila telah memiliki banyak uang maka dapat merasa bahagia, atau akan bahagia apabila telah memiliki mobil pribadi, ada pula yang mengatakan bahwa bahagia ketika memperoleh segala keinginan.

Kebahagiaan orang yang satu dengan lainnya relatif berbeda, karena sudut pandang menilai dan mengindikatorkan kebahagiaan tersebut dengan cara yang berbeda. Ketika ada yang bertanya pada seseorang "apakah kebahagiaan tersebut? , sudahkah mencapai kebahagiaan?". Mung- kin ada tidak langsung dapat menjawab pertanyaan-pertanyaan tersebut karena belum begitu jelas apa yang akan dijawab, tetapi hal yang ada di pikirkan dan dirasakan tentang kebahagiaan merupakan apa yang membuat seseorang nyaman dan apa yang dapat membuat merasa senang. Lalu apakah seseorang sudah merasakan kebahagiaan? Seseorang mungkin merasa bahagia apabila berada di lingkungan keluarga, dapat berbagi cerita serta merasakan kesenangan di sisi kekasih. Namun bukan berarti tidak bahagia ketika sendiri, orang merasa bahagia, karena sudah nyaman dengan dirinya sendiri dan tahu bagaimana seharusnya mensyukuri dan berterimakasih kepada diri sendiri.

Kebahagiaan dalam aspek psikologi sering dikaitkan dengan well-being atau kesejahteraan, menurut Ryan dan Deci (2001) tradisi well-being meliputi pende- 
katan hedonic dan pendekatan Eudaimonic. Pendekatan Hedonic menyatakan bahwa tujuan hidup adalah untuk mencapai kebahagiaan, kesenangan, mendapatkan kenikmatan serta terhindar dari rasa sakit, dalam penelitian tersebut banyak digunakan pemikiran mengenai Subjective Well being dimana SWB menyangkut tiga komponen yaitu kepuasan hidup, adanya gairah yang positif, dan tidak adanya gairah negatif di dalam membentuk suatu kebahagiaan. SWB meliputi pengalaman individu yang dipengaruhi oleh kesehatan, kenyamanan, kebijakan dan kebahagiaan yang di alami oleh individu tersebut( dalam Diener 1984) Tradisi Eudaimonic merupakan pandangan mengenai kebaha-giaan bukan dari hasilnya, melainkan pada proses untuk mencapai good life. Eudai-monic menggunakan Psychological well being untuk sebagai hal yang dapat mencapai good life.

Psycological well-being menurut Ryff (20010) merupakan kondisi dimana individu memiliki sikap yang positif terhadap dirinya sendiri dan orang lain, dapat membuat keputusan sendiri, memenuhi tujuan hidup, dan membuat hidupnya lebih bermakna serta berusaha mengeksplorasi dan mengembangkan dirinya serta memiliki kwalitas hubungan yang baik. Menurut, gambaran tentang karakteristik orang yang memiliki kesejahteraan psikologis merujuk pada pandangan Rogers tentang orang yang berfungsi penuh (fullyfunctioning person), pandangan Maslow tentang aktualisasi diri (self actualization) (Friedman H.S. \& Schustack M.W. 2006).

Mahasiswa yang masih dalam tahap perkembangan remaja tentu pernah merasakan suatu kebahagiaan selama proses panjang kehidupannya. Namun kebahagiaan sebenarnya bukanlah semata kebalik-an dari rasa sedih, kecewa atau hal yang berhubungan rasa tidak enak yang dialami seseorang. Apa yang dirasakan mahasiswa tentu tidak hanya berkutat pada masalah rasa senang atau tidak senang, bahagia atau sedih, tapi apakah rasa resebut dirasakan sesuatu yang dapat mempengaruhi diri sebelum atau sesudah suatu peristiwa. Tujuan utama dari pendekatan ini adalah untuk menciptakan ilmu pengetahuan yang lebih teliti, sistematis, universal yang secara teoritis maupun empiris dapat dibuktikan (Kim et al, 2006).

Budaya yang didalamnya ada konsep tentahng nilai-nilai, memiliki sumbangan berarti terhadap pembentukan konsep psikologis individu yang mungkin didapatkan individu secara turun temurun Seperti halnya konsep kebahagiaan. Kim dan Park (2006) menyebutkan bahwa budaya memiliki peranan yang sangat sentral dalam mempersepsi fenomena sosial. Oleh karena itu, dapat dipahami apabila suatu nilai kebahagiaan individu pasti dipengaruhi oleh konteks budaya yang berlaku. Uchida, dkk. (2004) dalam penelitiannya mengenai konstruksi kultural kebahagiaan, menemu-kan bahwa terdapat perbedaan makna kebahagiaan dikonteks budaya Barat (individualistik) dan Timur (kolektivistik). Secara spesifik dikonteks budaya Barat atau Amerika Utara, kebahagian memiliki kecenderungan definisi terkait dengan pencapaian prestasi pribadi (personal achievement). Pada konteks budaya ini individu bertindak karena termotivasi untuk memaksimalkan pengalaman afek positif. Self-esteem merupakan prediksi terbaik bagi kebahagiaan. Hal ini berkebalikan dengan konteks budaya Asia Timur, dimana kebahagiaan memiliki kecenderungan definisi terkait dengan pencapaian hubungan interpersonal. Pada konteks budaya ini individu bertindak karena termotivasi untuk mempertahankan keseimbangan antara afek positif dan negatif. Cara terbaik untuk memprediksi kebahagian dikonteks ini adalah dengan melihat kelekatan diri atau individu dalam hubungan sosial.

Peristiwa mencintai dan dicintai menjadi sumber kebahagiaan remaja karena remaja merasa senang ketika mereka menerima perawatan dari seseorang yang 
mereka suka, mereka merasa seolah-olah mereka sudah mendapat yang lebih baik harga diri, mereka merasa lebih dihargai dan dipahami, mereka merasa istimewa, dapat mengurangi rasa sakit (kesedihan), menciptakan rasa unik gratifikasi peningkatan motivasi dan mengakibatkan hubungan yang harmonis dengan orangorang di sekitar mereka. Di Asia masyarakat cenderung fokus pada ikatan antara satu sama lain. Kata kunci untuk kebahagiaan dalam Budaya Timur adalah kebersamaan atau hubungan. $\mathrm{Lu} \&$ Gilmour (2004) menyatakan bahwa kebahagiaan adalah hasil dari hubungan dengan orang lain. Dalam keluarga dan teman-teman, ada peristiwa mencintai satu sama lain dan menjadi sumber dukungan. Hubungan sosial juga memiliki efek yang luar biasa untuk kebahagiaan dan aspekaspek lain dalam makna hidup, dan dapat menjadi faktor terbesar tunggal.

\section{B. Tujuan Penelitian}

Tujuan umum penelitian ini adalah ingin mengetahui peristiwa-peristiwa seperti apa yang membuat individu dapat bahagia. Sedangkan tujuan khusus penelitian adalah ini mengetahui konsep secara indigenous psychology tentang peristiwa-peristiwa yang membuat individu bahagia.

\section{Landasan teori}

\section{Pengertian Kebahagiaan}

Secara fakta tidak mudah menemukan arti dari kabahagiaan. Karena kebahagiaan adalah sesuatu yang dirasakan daalam diri seseorang. Dari berbagai literature yang ada, semua pengerti mengarahkan bahwa kebahagiaan adalah subjective well-being (Uchida, dkk., 2004; Lyubomirsky dkk.,2005; Boven, 2005; Pavot, 2008). Namun ada juga yang berpendapat bahwa SWB meru pakan konsep lebih luas dan menyeluruh yang meliputi kebahagiaan itu sendiri. Pada beberapa penelitian istilah subjective wellbeing dipahami memiliki kesamaan makna dengan kebahagiaan.

Studi mengenai konsep kebahagiaan telah banyak dilakukan melalui berbagai perspektif. Masingmasing perspektif menyediakan berbagai penjelasan yang berbeda-beda mengenai apa yang dimaksud dengan kebahagiaan itu sendiri, yang pada akhirnya muncul hasil yang berbeda-beda pula mengenai bagaimana ke-bahagiaan itu bisa dicapai. Para pe-neliti seringkali menemukan kesulitan untuk merumuskan konsep mengenai kebahagiaan. Kata "kebahagiaan" ini memiliki makna yang beragam. Seringkali makna da-ri "kebahagiaan" (happiness) disamakan dengan "baik" (the good) ataupun "hidup yang bagus" (the good life) (Eddington \& Shuman, 2005). Namun demikian, beberapa peneliti mencoba untuk memaknai apa yang sebenarnya dimaksud dengan kebahagiaan.

Hamka (1988) mendasarkan teori pencapaian kebahagiaan kepada pemungsian, pemurnian, pengasahan dan penyempurnaan akal. Ia memandang akal sebagai alat, media dan sarana utama menemukan kebahagiaan. Meskipun ia tidak benar-benar konsisten, namun dapat disimpulkan bahwa ia berbeda dengan pandangan yang berlaku umum di kalangan filosof dan sufi tentang eksistensi akal.

Akal menurut Hamka, sesuai dengan fitrahnya, senantiasa condong ke atas (kemuliaan, kebenaran, kebaikan dan kesucian), sedangkan hawa nafsu condong ke bawah (kehinaan, kesalahan, keburukan dan dosa). Dengan demikian, akal membawa kepada kebahagiaan, sementara hawa nafsu membawa kepada kesengsaraan atau penderitaan.

Kebahagiaan merupakan konsep yang luas, seperti emosi positif 
atau pengalaman yang menyenangkan, rendahnya mood yang negatif, dan memiliki kepuasan hidup yang tinggi (Diener, Lucas, Oishi, 2005). Seseorang dikatakan memiliki kebahagiaan yang tinggi jika mereka merasa puas dengan kondisi hidup mereka, sering merasakan emosi positif dan jarang merasakan emosi negatif, selain itu kebahagiaan juga dapat timbul karena adanya keberhasilan individu dalam mencapai apa yang menjadi dambaannya, dan dapat mengolah kekuatan dan keutamaan yang dimiliki dalam kehidup-an sehari-hari, serta dapat merasakan sebuah keadaan yang menyenangkan (Diener dan Larsen, 1984, dalam Edington,2005).

$$
\text { Kebahagiaan diungkapkan }
$$

oleh Oishi dan Koo (2008), kebahagian adalah konstrak laten yang secara umum diindikasikan terbaik melalui tingkat kepuasan hidup. Kebahagiaan juga didefinisikan sebagai keung-gulan afek positif pada afek negatif dan sebagai kepuasan hidup yang menyeluruh (Argyle, Martin \& Crossland, 1989). Diener (2000) mendefinisikan subjective well-being (SWB) adalah keseluruhan penilaian kognitif mengenai kualitas kehidupan seseorang Seligman (2002), salah seorang pendiri aliran positive psychology, mendefinisikan kebahagiaan sebagai muatan emosi dan aktivitas positif. Veenhoven (1995) mendefinisikan kebahagiaan sebagai derajat sebutan terhadap kualitas hidup yang menyenangkan dari seseorang. Veenhoven menambahkan bahwa kebahagiaan bisa disebut sebagai kepuasan hidup (life satisfaction).

Kebahagiaan merupakan bahasan yang sangat berguna dan dianggap penting dibidang psikologi (Pavot, 2008) sejalan dengan berkembangnya bidang kajian positive psychology (Seligman, 2002). Telah banyak dikembangkan instrumeninstrumen pengukuran psikologi yang mengukur konstrak kebahagiaan, seperti Oxford Happiness Inventory, Life Satisfaction Scale, $P G C$ Morale Scale, dan sebagainya. Setiap alat ukur tersebut tentunya memiliki standar reliabilitas, validitas, dan objektivitasnya masingmasing. Umumnya instrument pengukuran kebahagiaan yang telah ada dikembangkan berbasis pada pendekatan general psychology. Namun berbagai penelitian mutakhir menyebutkan bahwa tidak semua teori-teori psikologi relevan disuatu daerah. Beberapa penelitian menyebutkan bahwa teori-teori psikologi sebenarnya berkaitan dengan batasan budaya (culture-bound), nilai-nilai daerah (value-laden) dan dengan validitas yang terbatas (Enriquez, 1993; Kim \& Berry, 1993; Koch \& Leary, 1985; Shweder, 1991, dalam Kim et al, 2006). Batasan-batasan kontekstual inilah yang membuat relevansi suatu teori psikologi tidak selalu kuat apabila diterapkan didaerah atau konsteks budaya lain.

Ahli lain seperti Diener (2003) mengartikan SWB sebagai penilaian pribadi individu mengenai hidupnya, bukan berdasarkan penilaian dari ahli, termasuk didalamnya mengenai kepuasan (baik secara umum, maupun pada aspek spesifik), afek yang me-nyenangkan, dan rendahnya tingkat afek yang tidak menyenangkan Hal tersebut akhirnya oleh Diener dijadi-kan sebagai komponen-komponen spesifik yang dapat menentukan tingkat SWB seseorang. Komponen-komponen tersebut antara lain: emosi yang menyenangkan, emosi yang tidak menyenangkan, kepuasan hidup secara global, dan aspek-aspek kepuasan (Diener, dkk, 2003).

Namun demikian Lyubomirsky dan Lepper (1997) memberikan 
kritik bahwa untuk menilai tingkat subjective well-being tidak cukup dengan melihat masing-masing komponen. Dibutuhkan penilaian global mengenai keseluruhan hidup yang lebih luas daripada hanya melihat afek, kepuasan hidup, dan aspekaspek kepuasan bagi individu. Hal ini didasarkan pada pemikiran bahwa kebanyakan orang dapat menilai dirinya sebagai orang yang bahagia atau tidak. Tidak hanya itu, kebanyakan orang juga dapat menilai orang lain sebagai orang yang bahagia atau tidak. Oleh karena itu, dibutuhkan sebuah istilah mengenai kebahagiaan yang tidak sekedar menilai kebahagiaan seseorang dari komponen-komponen subjective well-being. Lyubomirsky dan Lepper (1997) menyebutnya sebagai subjective happiness.

\section{Karakteristik Positif dari kebaha-} giaan

Seligman (2005) menyatakan terdapat enam nilai keutamaan (virtue) yang tergambar dalam 24 karakteristik kekuatan yang dapat membantu individu agar merasakan kebahagiaan atau mempertahankan tingkat kebahagiaan yang dimilikinya. Enam nilai keutamaan yang tergambar dalam 24 karakteristik kekuatan, yaitu:

1. Keutamaan (virtue ofwisdom and knowledge). Berkaitan dengan kemampuan kognitif dan bagaimana individu memperoleh dan menggunakan pengetahuan demi kebaikan. Terdiri dari kekuatankekuatan sebagai berikut:

a) Keingintahuan atau ketertarikan terhadap dunia (curiosity atau interest in the world). Keingintahuan dapat bersifat spesifik atau global (pendekatan yang mencermati segala hal) b) Kecintaan untuk belajar (love of learning).

c) Pertimbangan/pemikiran kritis (judgement/critical thinking). Seperti tidak terburu-buru dalam menarik kesimpulan, dan hanya bersandar pada bukti yang kuat untuk meng-ambil keputusan.

d) Kecerdikan/orisinalitas (Ingenuity/originality).

Tergambar dari bagaimana individu mengembangkan cara baru untuk meraih tujuan yang diinginkan dan kreatif mencakup ide orisinil dan adaptif.

e) Perspektif (perspective). Perspektif adalah kemampuan untuk mengambil pelajaran dalam hidup yang dapat dipahami oleh diri sendiri maupun orang lain.

2. Keutamaan (virtue of courage). Berkaitan dengan keberanian. kognisi, emosi, motivasi, dan keputusan yang dibuat. Terdiri dari kekuatan-kekuatan sebagai berikut:

3. Kepahlawanan dan ketegaran (valor and bravery). Ciri-ciri individu ini adalah berani ketika muncul ancaman, tantangan, kepedihan, kesulitan, dan saat kesejahteraan fisik terancam. Kepahlawanan mencakup keberanian moral seperti mengambil sikap yang disadari dapat merugikan diri sendiri dan keberanian psikologis seperti ketabahan saat menghadapi musibah.

a) Rajin/tekun (perseverance). Individu memiliki semangat untuk menyelesaikan tugasnya dan tidak banyak mengeluh, mampu bersifat fleksibel, realistis, dan tidak prefeksionis. 
b) Integritas (integrity). Individu mengucapkan kebenaran dan menampilkan niat serta komitmen diri pada orang lain dan diri sendiri dengan cara yang tulus baik melalui perkataan maupun perbuatan.

c) Semangat/gairah/antusiasme (zest/passion/enthusiasm). Individu memiliki semangat saat memulai hari baru dan melibatkan jiwa raga pada aktivitas yang dijalani.

4. Keutamaan berkaitan dengan kemanusiaan dan cinta (virtue ofhumanity and love) Diperlihatkan dalam interaksi sosial positif dengan orang lain (kekuatan interpersonal). Yang terdiri dari kekuatan sebagai berikut:

a) Kebaikan dan kemurahan hati (kindness and generousity). Selalu bersikap baik dan penolong, memperhatikan kepentingan orang lain sama seriusnya dengan kepentingan dirinya, menghargai orang lain, empati, dan simpati.

b) Mencintai dan bersedia dicintai (loving and allowing oneself to beloved). Hal utama adalah kemammpuan dan kemauan untuk memberi dan menerima cinta, adanya perasaan kedekatan dan keakraban dengan orang lain.

c) Kecerdasan sosial/kecerdasan pribadi/kecerdasan emosional (social intelligence/personal intelligencelemotional intelligence).

5. Keutamaan berkaitan dengan keadilan (virtue of justice). Muncul pada aktivitas bermasyarakat yang mencakup hubungan interpersonal. Terdiri dari kekuatan-kekuatan sebagai berikut:

a) Kewarganegaraan (citizenship). Mampu mengidentifikasi dan berkewajiban terhadap kepentingan bersama yang mana individu merupakan anggota dari setiap kelompok.

b) Keadilan dan persamaan (fairness and equity). Individu memperlakukan orang lain dengan tidak membiar-kan masalah pribadi menyebabkan bisa terhadap kepu-tusannya tentang orang lain dan memberikan kesem-patan yang sama pada setiap orang.

c) Kepemimpinan (leadership).

6. Keutamaan berkaitan dengan kesederhanaan (virtue of temperance). Merujuk pada pengekspresian yang pantas dan wajar dari keinginan diri. Individu tidak menekan keinginan tapi menunggu kesempatan untuk memenuhinya. Terdiri dari kekuatan-kekuatan sebagai berikut:

a) Pengendalian diri (selfcontrol). Kemampuan untuk menahan nafsu pada saat yang tepat, mengatur emosi ketika terjadi hal buruk, memperbaiki dan menetralkan perasaan negatif, serta tetap memiliki emosi positif ketika menghadapi cobaan.

b) Kehati-hatian atau penuh pertimbangan (prudence). Mendengar pendapat orang lain sebelum bertindak, berwawasan jauh dan penuh pertimbangan, serta pandai menahan dorongan hati demi kesuksesan jangka panjang.

c) Kerendahan hati dan kebersahajaan (humility and modesty). Tidak menganggap diri sendiri 
lebih istimewa dibandingkan orang lain dan dapat menyadari kesalahan serta kekurangan diri.

d) Sikap pemaaf dan belas kasih (forgiveness and mercy). Mam-pu memaafkan dan tidak membalas perbuatan orang yang telah menyakitinya.

e) Keutamaan berkaitan dengan transendensi (virtue of trancendence). Transendensi merupakan kekuatan emosi yang menjangkau keluar diri untuk menghubungkan diri sendiri ke sesuatu yang besar atau permanen, misalnya kepada masa depan, ketuhanan atau alam semeta. Terdiri dari kekuatan-kekuatan sebagai berikut:

a) Apresiasi terhadap keindahan dan keunggulan (appreciationofbeauty and excellence)

b) Spiritualitas/keyakinan/keag amaan (spirituality). Individu memiliki filosofi hidup yang jelas dan memiliki kepercayaan yang membentuk tindakannya.

c) Harapan atau Optimism atau berpikiran ke depan (hopel

optimism/futuremindedness)

Berharap mendapat yang terbaik untuk masa depan dan merencanakan serta bekerja keras untuk meraihnya.

d) Bersyukur (gratitude). Bersyukur berarti sebuah penghargaan terhadap kehebatan karakter moral orang lain. Sebagai sebuah emosi, kekuatan ini berupa ketakjuban, rasa terima kasih, dan apresiasi terhadap kehidupan. Dapat ditujukan kepada Tuhan, alam, dan binatang tetapi tidak dapat ditujukan untuk diri sendiri.

Hamka (2002) seorang filsuf, ulama dan sastrawan, Islam mengajarkan pada manusia empat jalan untuk menuju kebahagiaan. Pertama, harus ada i'tiqad, yaitu motivasi yang benar-benar berasal dari dirinya sendiri. Kedua, yaqin, yaitu keyakinan yang kuat akan sesuatu yang sedang dikerjakannya. Ketiga, iman, yaitu yang lebih tinggi dari sekedar keyakinan, sehingga dibuktikan oleh lisan dan perbuatan. Tahap terakhir adalah addiin, yaitu penyerahan diri secara total kepada Allah, penghambaan diri yang sempurna. Mereka yang menjalankan ad-diin secara sempurna tidaklah merasa sedih berkepanjangan, lantaran mereka benar-benar yakin akan jalan yang telah Allah pilihkan untuknya.

Lebih lanjut HAMKA menjelaskan teori pencapaian kebahagiaan kepada pemungsian, pemurnian, pengasahan dan penyempurnaan akal. Ia memandang akal sebagai alat, media dan sarana utama menemukan kebahagiaan. Meskipun ia tidak benar-benar konsisten, namun dapat disimpulkan bahwa ia berbeda dengan pandangan yang berlaku umum di kalangan filosof dan sufi tentang eksistensi akal.

Akal menurut Hamka, sesuai dengan fitrahnya, senantiasa condong ke atas (kemuliaan, kebenaran, kebaikan dan kesucian), sedangkan hawa nafsu condong ke bawah (kehinaan, kesalahan, keburukan dan dosa).Dengan demikian, akal membawa kepada kebahagiaan, sementara hawa nafsu membawa kepada kesengsaraan atau penderitaan.

Kebahagiaan tertinggi yang dapat dicapai akal adalah ma'rifatullah, yakni mengenal Allah 
Happiness Aitem 1 lev 2

\begin{tabular}{llcccc}
\hline & & Frequency & Percent & Valid Percent & Cumulative Percent \\
\hline \multirow{5}{*}{ Valid } & RELASI & 228 & 58.0 & 58.0 & 58.0 \\
\cline { 2 - 6 } & PRESTASI & 93 & 23.7 & 23.7 & 81.7 \\
\cline { 2 - 6 } & $\begin{array}{l}\text { PERSONAL } \\
\text { AFEKTIF }\end{array}$ & 72 & 18.3 & 18.3 & 100.0 \\
\cline { 2 - 6 } & Total & 393 & 100.0 & 100.0 & \\
\hline
\end{tabular}

dengan kualitas haqq al-yaqin. Inilah puncak kebahagiaan, kenikmatan dan kelezatan, yang diistilahkan Hamka sebagai kebahagiaan sejati atau kebahagiaan utama. Karena kebaha-giaan sejati itu adalah mengenal Allah, maka jalan utama menuju pengenalan terhadap Allah (ma'rifatullah) adalah dengan mem-berdayakan akal.

\section{METODE PENELITIAN}

Responden penelitian ini adalah sebanyak 220 remaja SMA, remaja lakilaki sebanyak 51 orang dan remaja perempuan sebanyak 159 orang di kota Pekanbaru. Penelitian ini menggunakan instrument berupa kuesioner dengan pertanyaan terbuka yang telah dikembangkan oleh Kim (2008) dan kemudian disusun kembali oleh Center for Indigenous \& Cultural Psychology (CICP) Fakultas Psikologi UGM. Pertanyaan terbuka adalah per-tanyaan yang variasi jawabannya dan belum ditentukan terlebih dahulu, sehingga resonden mempunyai kebebasan untuk menjawab dari pertanyaan yang diajukan. Adapun pertanyaan terbuka yang diajukan adalah "Mengapa anda bangga akan prestasi yang anda nilai paling penting tersebut? Kemudian jawaban partisipan dikategorisasikan dalam kategori-kategori kecil yang berbeda.

Kategorisasi dilakukan oleh tim validasi yang terdiri dari para dosen dan mahasiswa yang menjadi asisten di Center for Indigenous and Cultural Psychology UIN Suska Riau. Selama proses kategorisasi jawaban partisipan dipisahkan sesuai dengan kategori kecil kemudian jawaban dan kategori kecil divalidasi oleh tim validasi selanjutnya kategori kecil dimasukkan dalam (teori atribusi). Langkah-langkah dalam kategorisasi adalah mengumpulkan data untuk dianalisis, mengidentifikasi tema sesuai dengan kategori yang relevan dengan penelitian ini, menganalisis kategori sesuai dengan topik penelitian. Data yang diperoleh dianalisis dengan menggunakan tabulasi silang, yaitu dengan memasukkan data-data kuantitatif yang sudah diolah sebelumnya dan data kualitatif yang sudah dikuantitatifkan dalam SPSS (Statistic Package for Social Sciences) for windows version 18.0.

\section{HASIL DAN PEMBAHASAN}

\section{Hasil}

Dari hasil analisis data-data kuantitatif dan data kualitatif, maka diperoleh hasil, dimana peristiwa-peristiwa yang membuat remaja bahagia adalah peristiwa yang berhubungan dengan relasi sebesar $58,0 \%$, peristiwa yang berhubungan dengan prestasi sebesar $23,7 \%$ dan peristiwa yang berhubungan dengan personal afektif sebesar 18,3\%.. Pada peristiwa yang berhubungan dengan relasi adalah orang tua, teman dan keluarga. Prestasi berhubungan dengan prestasi, lulus, keinginan tercapai, hasil yang memuaskan, mampu menyelesaikan tugas, dan melahirkan dan memiliki anak. Pada peristiwa personal afektif adalah lawan jenis, mendapatkan kasih sayang, membantu orang lain, hobi, mendapatkan kejutan, menikah, imbalan psikologis, ulang tahun dan agama.

Hasil data penelitian apabila dilihat dari jenis kelamin, didapatkan hasil pada peristiwa personal afektif wanita $12,0 \%$ 
dan pria sebesar 5,3\%. Pada peristiwa wanita sebesar $15,0 \%$ dan pria sebesar 7,6. Dan peristiwa relasi $43,0 \%$ dan pria sebesar $13,0 \%$.

\section{Pembahasan}

Hasil penelitian ini menunjukkan bahwa relasi atau hubungan dengan orang lain menempatkan orang tua sebagai peristiwa yang dapat membuat remaja bahagia, kemudian keluarga dan teman. Hal ini dimungkinkan terjadi karena orang tua adalah orang yang pertama kali dekat dengan remaja dan selalu ada, orang tua dapat mengetahui dan menerima remaja. Disamping itu orang tua yang mendidik dan membimbing remaja.

Keluarga adalah kumpulan dari seluruh individu dalam satu keturunan. Hal ini menjadi berarti bagi remaja untuk membantu ketika remaja dalam kesulitan dan dalam satu keluarga ada saling mencintai dan saling ada ketergantunga sama lain. Orang tua merupakan figur penting dalam kehidupan seorang remaja. Relas dan peran orang tua pada masa remaja sangat penting bagi perkembangan diri remaja (Dirgagunarsa \& Sutantoputri, 2004). Relasi yang baik antara orang tua dan remaja yang telah dibina sejak lahir akan menimbulkan adanya keterikatan (attachment) atau ikatan relasi satu sama lain. Hetherington dan Parke (2003) mengemukakan bahwa keterikatan adalah hubungan, mengembangkan interaksi antara orang tua dan anak. Relasi atau hubungan orang tua dengan anak remaja pada keluarga normal terlihat adanya afeksi yang hangat antara orang tua terhadap anak remaja dan remaja terhadap orang tua (Dirgagunarsa \& Sutantoputri, 2004).

Selain ikatan afeksi, relasi remaja dengan orang tua juga dikarakteristikkan dengan komunikasi yang baik dan identifikasi yang kuat (Rice, 2002). Menurut Kelley relasi antara orang tua dan remaja dapat menimbulkan sikap saling tergantung satu sama lain, dan relasi tersebut bertahan dalam waktu periode yang lama. Dari penelitian yang dilakukan oleh Holmbeck, et. al ditemukan bahwa ikatan relasi yang hangat, mendalam dan berkualitas antara orang tua dan remaja mampu membantu remaja dalam mengatasi perubahan-perubahan yang terjadi dalam dirinya. Orford menemukan bahwa suatu relasi yang berkualitas dapat dilihat dari seberapa jauh relasi tersebut memberikan fungsi-fungsi dukungan sosial yang penting, seperti pertolongan, perhatian, suatu pengakuan, dan pendampingan.

Hasil penelitian ini sejalan dengan hasil penelitian yang dilakukan oleh Anggoro dan Wdhiarso (2010) dimana ditemukan bahwa ada empat aspek indikator kebahagiaan yaitu ikatan dan rasa kekeluargaan, prestasi atau pencapaian pribadi, relasi social dan kebutuhan spiritual. Ryff (dalam Rahayu, 2008) menyatakan salah satu dimensi dari psychological well being adalah hubungan positif dengan orang lain. Kemampuan untuk berhubungan dan mencintai orang lain dipandang sebagai komponen utama dari kondisi mental yang sehat.

Menurut teori keterikatan (dalam Lucia, 2000) keterikatan adalah hubungan afektif yang relatif stabil sifatnya antara anak dengan satu orang atau orang yang khusus secara terus menerus. Bowlby (dalam Lucia, 2000) mengemukakan bahwa keterikatan merupakan ikatan yang ada pada hubungan antara individu dengan objek lekatnya, sehingga merupakan kecenderungan yang stabil untuk selalu mencari keterikatan dan kontak dengan figur-figur khusus sebagai figur lekat sepanjang waktu.

Selanjutnya dalam penelitian Oetami P. \& Kwartarini WY (2011) menemukan bahwa salah satu peristiwa yang dapat remaja bahagia adalah keluarga. Yang masuk dalam kategori kaluarga dalam penelitian tersebut adalah dicintai orangtua, kebersamaan dengan keluarga, bertemu ibu/ayah, liburan dengan kelurga, membahagiakan keluarga, membahagiakan orangtua, membanggakan orangtua, membantu keluarga, memiliki keluarga 
harmonis dan bahagia, memiliki orangtua yang baik, mempunyai adik, serta selamat dari musibah. Oetami P. \& Kwartarini WY juga menemukan bahwa peristiwa yang dapat membuat bahagian adalah yang berhubungan prestasi.

\section{SIMPULAN}

Peristiwa-peristiwa yang membuat orang bahagia dalam penelitian ini berhubungan dengan tiga dimensi yaitu relasi dengan orang lain tertuma dengan keluarga, kebutuhan afeksi dan prestasi. Ketiga dimensi tersebut adalah sesuatu yang dapat dirasakan secara individual. Dalam kehidupan seseorang peristiwaperistiwa tersebut merupakan sesuatu yang berharga dan diberikan nilai yang lebih daripada yang lainnya.

\section{DAFTAR PUSTAKA}

Boven, V. L. (2005). Experientialism, Materialism, and the Pursuit of Happiness. APA Review of General Psychology, Vol. 9, No. 2, 132-142. Washington: Educational Publishing Foundation.

Diener, E. \& Scollon, C. 2003. Subjective well being is desirable, but not the summon bonum. Paper delivered at the University of Minnesota interdisciplinary Workshop on WellBeing, October 23 - 25, 2003, Minneapolis

Diener, E., Suh, E.M., Lucas, R.E., \& Smith, H.L. 2005. Subjective WellBeing: Three Decades of Progress. Psychological bulletin, 125, 276302.

Dirgagunarsa, Y. S., \& Sutantoputri, N. W, "Hubungan orang tua dan remaja", Dalam Singgih D. Gunarsa (Editor), Dari anak sampai lanjut usia: Bunga rampai psikologi perkembangan, BPK Gunung Mulia, Jakarta, 2004.

Emmons, R. A., \& McCullough, M. E. 2003 Counting blessings versus burdens: An experimental investigation of gratitude Argyle, Martin \& Crossland, 1989).

Friedman H.S. \& Schustack M.W. 2006, Psikologi Kepribadian (teori Klasik dan Riset Modern) jilid 2, Jakarta: Erlangga (terjemahan)

Hamka 2002. Falsafah Hidup, Cet.XIII.Jakarta: Pustaka Panjimas, .

Hetherington, E. M., \& Parke, R. D, "Child psychology: A contemporary viewpoint", (5th ed.) McGraw-Hill, New York, 2003.

Kim, U., Yang, K., Hwang, K. (2006). Contributions to Indigenous and Cultural Psychology: Understanding People in Context. Dalam Kim, U., Yang, K., Hwang, K., (Eds). Indigenous and Cultural Psychology: Understanding People in Context. New York: Springer.

Lu, L., Gilmour, R., \& Kao, S. (2001). Cultural Values and Happiness: an East-West Dialogue, The Journal of Social Psychology, 141 (4), 477-493.

Lucia, D. D, "Kelekatan dan attachment coping behavior pada remaja putri" Phronesis: Jurnal ilmiah psikologi terapan. 2, 4, 56-65, Universitas Tarumanagara, Jakarta, 2000. Veenhoven, 1995

Lyubomirsky, S., Sheldon K., \& Schkade D. (2005). Pursuing Happiness: The Architecture of Sustainable Change. APA Review of General Psychology, Vol. 9, No. 2, 111-131. Washington: Educational Publishing Foundation

Pavot, W. (2008). The Assesment of Subjective well-Being. Dalam Eid M.

\& Larsen R. J. The Science of Subjective Well-Being. New York: Guilford Press.

Primasari, Ardi, Yuniarti, Kwartarini Wahyu , What Make Teenagers Happy? An Exploratory Study Using Indigenous Psychology Approach International Journal of Research Studies In Psychology 2012 June, Volume 1 Number 2, 53-61

Putri Oetami \& Kwartarini Wahyu YuniartiHumanitas, 2011, Orientasi 
Kebahagiaan Siswa Sma, Tinjauan Psikologiindigenous Pada Siswa Laki-Laki Dan Perempuan Jurnal Humanitas, Vol. VIII No.2 Agustus 2011.

Rice, F. P., \& Dolgin, K. G, "The adolescent: Development, relationships, and culture", $\left(10^{\text {th }}\right.$ ed.), MA: Allyn \& Bacon, Boston, 2002.

Russell, J.E.A. 2008. Promoting Subjective Well-Being at Work. Journal of Career Assessment, 16: 118-132.
Seligman, M. (2002). Authentic happiness: Using the new positive psychology to realize your potential for lasting fulfillment. New York: Free Press.

Uchida, Y., Norasakkunkit, V., Kitayama, S., (2004). Cultural Constructions of Happiness: Theory and Empirical Evidence. Journal of Happiness Studies, 5: 223-239. Netherlands: Kluwer Academic. 